\title{
Hydroxychloroquine in the post-COVID-19 era: will this pandemic upset decades of clinical practice?
}

\author{
Lucie Pothen $^{1}$ (D) $\cdot$ Halil Yildiz $^{1} \cdot$ Mathilde Mbouck Samnick ${ }^{2} \cdot$ Jean Cyr Yombi ${ }^{1}$
}

Received: 1 September 2020 / Revised: 22 December 2020 / Accepted: 25 December 2020 / Published online: 15 January 2021

(C) International League of Associations for Rheumatology (ILAR) 2021

\begin{abstract}
In the early stage of the COVID-19 pandemic, Belgian health authorities endorsed the interim guidelines for the treatment of COVID-19 pneumonia: hydroxychloroquine (HCQ) recommended for treatment of hospitalized patients with moderate to severe disease. As a growing number of patients were admitted, inevitably, our internal medicine team questioned the efficacy and safety of HCQ, especially with regard to cardiac side effects. In parallel with our concerns, data regarding the safety and efficacy of HCQ were published, with discordant results and debate in the medical community. Media coverage of the possible risks and benefits of HCQ use in COVID-19 also caused confusion amongst the public. In this Perspectives in Rheumatology article, we review the use and safety of HCQ in autoimmune disease and its putative efficacy and toxicity in COVID-19. Finally, we share our concern about the future of this widely used and inexpensive drug after the COVID-19 pandemic has passed.
\end{abstract}

Keywords Autoimmune disease $\cdot$ COVID-19 $\cdot$ Hydroxychloroquine $\cdot$ Systemic lupus erythematosus $\cdot$ Toxicity

\section{Introduction}

In the early stage of the COVID-19 pandemic, in March 2020, Belgian health authorities endorsed the interim guidelines for the treatment of pneumonia: hydroxychloroquine (HCQ) was recommended for COVID-19 hospitalized patients with moderate to severe disease. The regimen included HCQ at the dose of $400 \mathrm{mg}$ twice on day 1 followed by $200 \mathrm{mg}$ twice daily from day 2 to day 5 . Our teaching hospital of 1000 beds set up dedicated COVID-19 wards, and a growing number of patients were admitted. Inevitably, questions arose within our teams of internal medicine and infectious disease specialists about the efficacy and safety of HCQ, especially of possible cardiac side effects. Two main questions were as follows: Does it work? And, at the dosage used, could it be toxic? These two issues prompted heated debate. The internal

Lucie Pothen

lucie.pothen@uclouvain.be

1 Department of Internal Medicine and Infectious Diseases, Cliniques Universitaires Saint-Luc, Université de Louvain (UCLouvain), 10 avenue Hippocrate, 1200 Brussels, Belgium

2 Department of Internal Medicine and Cardiology, Saint Georges Hospital, Blackshaw Road, London SW17 OQT, UK medicine group was confident that the drug was safe at the dosage they used, confidence that was probably based on their long experience of using it for the treatment of the common autoimmune disorders (systemic lupus erythematosus, primary Sjögren's syndrome, and sarcoidosis). However, infectious disease colleagues had reservations about the risk of prolonged corrected QT interval (QTc), mostly over HCQ used in association with antibiotics such as quinolones and macrolides (azithromycin). An electrocardiogram performed prior to the start of each treatment was made compulsory. Neither the internal medicine nor the infectious disease specialists, though, had witnessed a case of sudden death due to torsade de pointes linked to the use of HCQ.

Review of the literature on significant adverse effects linked to HCQ usage also was reassuring. For COVID-19, the use was off-label, having at heart the "Do no harm" principle. Nevertheless, we had to consider the context in which we were treating patients at the height of this new disease, with little known about how to prevent fatalities.

Now, with the flattening of the first wave of COVID-19, we have real-life data from our cohort of patients treated with HCQ, with or without azithromycin. Given at the recommended dose from a standard protocol (short, 5-day duration; baseline ECG prior to starting treatment; control ECG during combined treatment; and blood monitoring and correction of electrolyte disturbance), we have not noticed a concerning number 
of cardiac-related events directly attributed to the abovementioned medications [1]. We remain confident about the safety of HCQ, but we were not able to answer the question of its efficacy.

\section{HCQ and autoimmune diseases}

For more than 50 years, HCQ has been the main treatment of the commonest autoimmune diseases: systemic lupus erythematosus (SLE), primary Sjogren's syndrome, rheumatoid arthritis, antiphospholipid syndrome, and sarcoidosis. Its immunomodulatory properties are the mainstay to prevent flare-ups and promote long-term survival.

The proposed mechanisms of HCQ's action are based on in vitro studies; their link with clinical efficacy has not been elucidated. In summary, HCQ increases the $\mathrm{pH}$ of lysosomes and other intracellular compartments, leading to interference in phagocytosis, change in antigen presentation, and interference with Toll-like receptor 7 and 9 signalling pathways. HCQ also blocks $\mathrm{T}$ cell response and reduces production of pro-inflammatory cytokines (INF-gamma, TNF, IL-1, and IL6). Finally, it stimulates nitrite oxide production by endothelial cells to produce an anti-thrombotic effect by inhibiting platelet aggregation and acting on antiphospholipid antibodies $[2,3]$.

The clinical benefit of HCQ has been largely demonstrated in SLE, with proven control on disease activity; decrease in flare-ups, particularly during pregnancy and breastfeeding; reduction in thrombotic events; and reduction in mortality $[2,3]$. Use of HCQ in SLE has also been associated with reduction in the rate of cardiovascular complications, lowering of fasting glucose levels, and improvement in lipid profile $[2,3]$. HCQ is, therefore, amongst the most recommended treatments for SLE worldwide [4]. In rheumatoid arthritis patients, HCQ has had a significant effect on controlling the disease in its early and mild forms [5]; as in SLE, improvement of lipid profile and insulin resistance have been demonstrated [3], alongside a reduction in cardiovascular events [6].

Several retrospective studies have reported HCQ to be protective against infections. It was associated with a 16-times decrease in major infection risk in the Lupus-Cruces cohort [7] and an odds ratio of 0.05 in favour of HCQ in a Dutch cohort of SLE patients [8]. This association has been observed also amongst rheumatoid arthritis patients [9]. One explanation for this protective effect could be that HCQ exerts in vitro properties against viral, bacterial, and even fungal pathogens by way of the aforementioned actions (increase in lysosomal and phagolysosomal $\mathrm{pH}$ and interference with antigen presentation) but also by protein glycosylation that prevents viral shedding [10]. Another explanation would correlate this protective effect to patients treated with HCQ having a mild form of the underlying autoimmune disease, thus not relying on other immunosuppressive treatment [8].

Hence, HCQ is strongly recommended in the management of the prominent autoimmune diseases, such as SLE, rheumatoid arthritis, antiphospholipid syndrome, and primary Sjogren's syndrome (articular manifestations), and as part of the management of sarcoidosis (pulmonary, articular, or cutaneous). The usual dose is 200 to $400 \mathrm{mg} /$ day, with a maximum dose of $5 \mathrm{mg} / \mathrm{kg} /$ day.

\section{Toxicity/safety of HCQ in autoimmune diseases}

HCQ is considered mainly an immunomodulator rather than an immunosuppressive drug, and it has a good safety profile. The most common adverse effects are gastrointestinal symptoms (nausea, diarrhoea, and abdominal discomfort). To prevent these adverse effects, HCQ is best taken during meals [2, $3]$.

The most severe toxicity related to HCQ is retinopathy associated with long-term use (more than 12 months) and the cumulative dose effect. HCQ causes lipofuscin accumulation in retinal pigment epithelium due to lysosomal degradation of the external receptor [11]; the result is circular defects known as "bull's eye maculopathy." Unfortunately, the retinopathy can progress for several months, even after discontinuation of treatment. Appropriate dosage $(<5 \mathrm{mg} / \mathrm{kg} /$ day $)$ alongside usage of advanced screening modalities of ocular toxicity can prevent the occurrence of this adverse effect.

Other less frequent adverse outcomes with HCQ, such as myopathy (with proximal muscle weakness or atrophy, but typically without myalgia or increased muscle enzymes), have been reported with HCQ use. Improvement can be achieved by discontinuing the drug $[3,12]$. Cutaneous and neurological toxicity also have been reported [3]. Finally, cardiac toxicity has occurred, ranging from rhythm disorders to cardiomyopathy $[2,3]$. Patient's age, duration of use, pre-existing heart conditions, use of high doses, and renal failure are aggravating risk factors for cardiotoxicity [3]. HCQ can cause long-QT syndrome due to blockade of the Kv11.1 (hERG) channel [13]. The clinical manifestation of the electrical disturbance of the heart (syncope and torsade de pointes) mostly occurs with long-term use; simultaneous use of other long-QTc medications (azithromycin, quinolones, and others); electrolyte disturbance; renal failure; or an acute overdose. Before the pandemic, one case of ventricular arrhythmia due to HCQ used alone had been reported [14]. McGhie et al. [15] reported 453 SLE patients with $0.7 \%$ cases of prolonged QTe with no ventricular arrhythmia. Unpublished post-marketing data from Sanofi $(n=21,446)$ related 137 adverse drug reactions $(0.64 \%)$ of cardiac nature, with 19 torsade de pointes $(0.09 \%)$ with 1 fatal outcome; this result is consistent with the US Food 
and Drug Administration database (FAERS) analysis of 1968 to early 2020 , in which 57 HCQ-linked adverse events were recorded, with 10 deaths attributed to cardiac arrhythmias (torsade de pointes and prolonged-QTc syndrome) [16].

HCQ in the treatment of autoimmune diseases is considered one of the safest uses of the drug. Ordinarily, patients are followed clinically and biologically on a regular basis, e.g., every 3 to 6 months, and educated on their disease and treatment. Common recommendations for HCQ treatment include regular screening for retinal toxicity (every 6 months) and physical examination with attention to muscle strength and reflexes. HCQ should be avoided in patients who have congenital long-QT syndrome or persistently corrected QT measurements $>500 \mathrm{~ms}$, and who are taking other drugs that prolong the QT interval; consideration should be given to discontinuing these drugs [3].

\section{HCQ in COVID-19 disease}

As reported [10], HCQ has in vitro activity against pathogens, either bacterial, fungal, or viral, including in vitro activity against SARS-CoV-2 [17]. However, HCQ's antiviral effects were not evident in life-like models of infection with human respiratory cells. Also, no therapeutic benefit was derived in a SARS-CoV-2 infection model in hamsters and non-human primates [18]. Through other mechanisms of action, though, HCQ may be effective in treating the second phase of COVID-19, that is, a syndrome characterized by a "cytokine storm" involving an IL-6 and interferon response, thrombotic events, and endothelial dysfunction [19].

HCQ was used for the first time in China at an early stage of the pandemic in a small randomized controlled trial of 62 patients to improve pneumonia regression and reduce the recovery time [20]. HCQ then was included in national recommendations in many countries as part of the strategy to fight the pandemic. Table 1 lists the main studies where HCQ was used in the treatment of COVID-19, e.g., retrospective studies of more than 1000 patients and randomized controlled studies [21-40]. Whilst most retrospective studies reported clinical improvement with HCQ, randomized controlled studies were stopped because of inefficacy and, eventually, a tendency towards increased overall mortality. The discrepancies between the retrospective studies and the randomized controlled studies have not been explained. HCQ doses were higher, particularly in the Recovery and Solidarity HCQ arms [36, 38], than in retrospective studies, but this was not the case in the Orchid or Cavalcanti trial $[37,39]$. Another possible explanation could be differences in the time of initiation of HCQ treatment; in the Recovery trial, the median time between symptom onset and randomization was 9 days, with $16.7 \%$ of patients already on mechanical ventilation at randomization. In contrast, HCQ was initiated within the first day after admission in the Catteau and Lammers studies [25, 30].

On July 4, 2020, the World Health Organization announced that it had stopped HCQ and lopinavir/ritonavir arms in their clinical trials, Solidarity and Discovery, respectively. The conclusion was that both drugs added little or no benefit in reducing mortality. HCQ now is not being used in the treatment of COVID-19, but it remains a subject of debate [41].

\section{Cardiac toxicity of HCQ in COVID-19 disease}

Published safety data on HCQ use in COVID-19 have also revealed discordant results: Mercuro et al. [42], without comment regarding efficacy, found that $19 \%$ of 90 patients had prolonged QTc, and "one torsade de pointes" occurred. Gerard et al. [43] reviewed the French Drug Agency reports of adverse drug reaction at an early stage of the pandemic and found 103 of 120 cases of cardiac adverse drug effect linked to HCQ; within the 131 reported effects, $3.0 \%$ were sudden or unexplained deaths, $6.1 \%$ were ventricular arrhythmias, and 68.7\% were prolonged QTc. In contrast, most retrospective studies reported no adverse effect of HCQ, although QTc prolongation was present in some subjects (Table 1). In particular, the Rosenberg cohort [32] had an increase in arrhythmias (16\% vs $10 \%$ ) and almost 2 times more cardiac arrests in the HCQ arm (13\% vs 6.8\%). In the large-scale cohort study by Mehra et al. [35], published in The Lancet (retracted), an increase in arrhythmia risk was also described, with $6.1 \%$ of patients with de novo ventricular arrhythmia.

Once again, an increase in cardiac events was not substantiated in randomized controlled studies (Table 1). Similarly, the prospective study of Gasperetti et al. [44] of 649 COVID19 patients treated with HCQ, either at home, in hospital, or in ICU, found no increase in arrhythmia-related cases or deaths despite a relative increase in prolonged QTc. Interestingly, in that study, baseline QTc length and fever at admission were the most important determinants of QT/QTc prolongation [44].

What could contribute to higher risks of cardiac events with HCQ treatment of COVID-19 than with autoimmune disease? First, SARS-CoV-2 infection itself can injure cardiac myocytes, leading to arrhythmic events. Indeed, the results of early studies suggested that COVID-19 is associated with a high incidence of cardiac arrhythmias. Bhatla et al. [45] reported that amongst 700 patients (11\% received ICU care), 9 cardiac arrests, 25 incident atrial fibrillation events, 9 clinically significant bradyarrhythmias, and 10 non-sustained ventricular tachycardia events occurred. Second, electrolyte disturbances, e.g., hyperkalemia or acute kidney injury, frequently occur during the disease [46]. These abnormalities directly increase the risk of arrhythmia by potentializing the QTc 


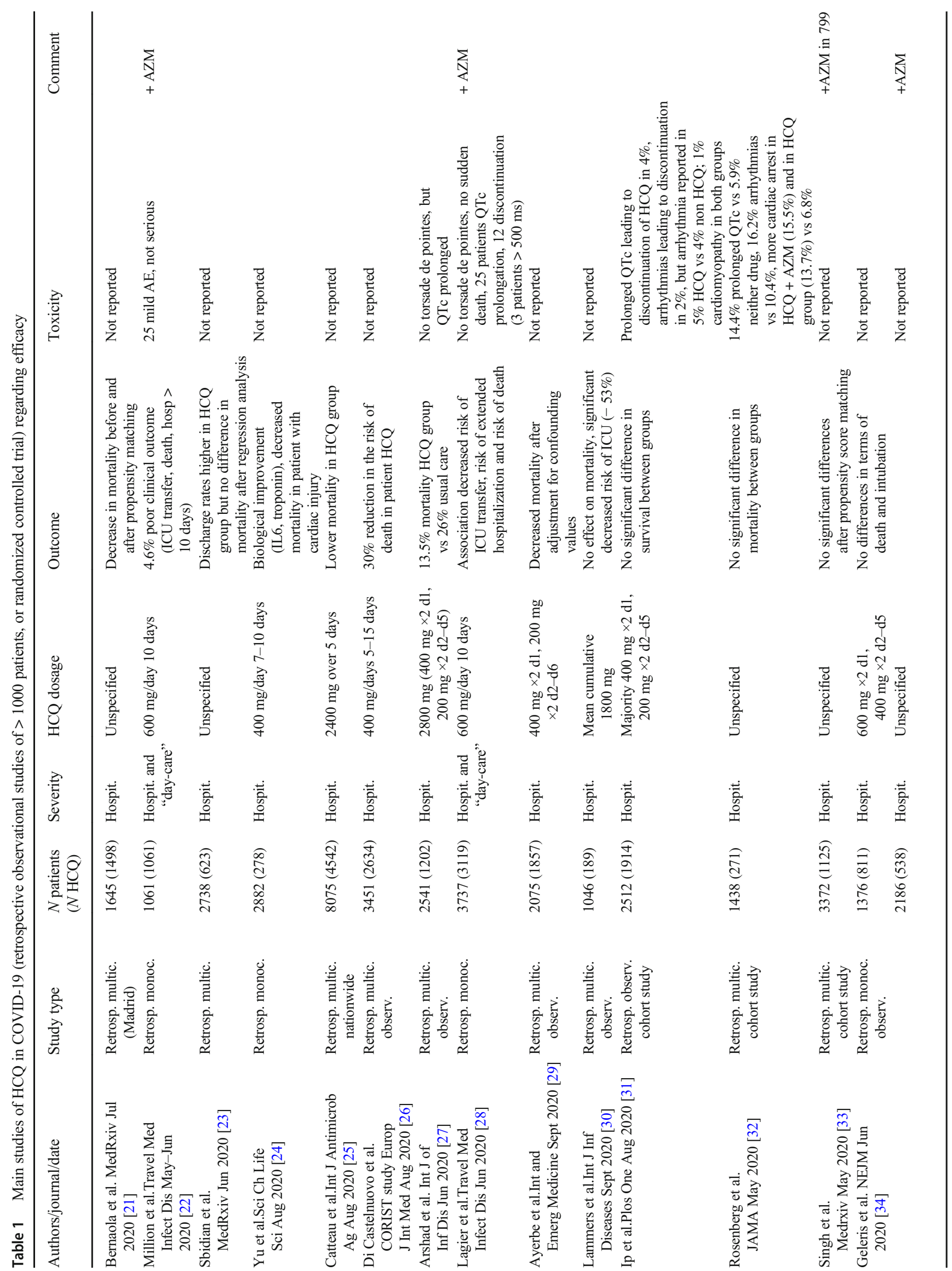




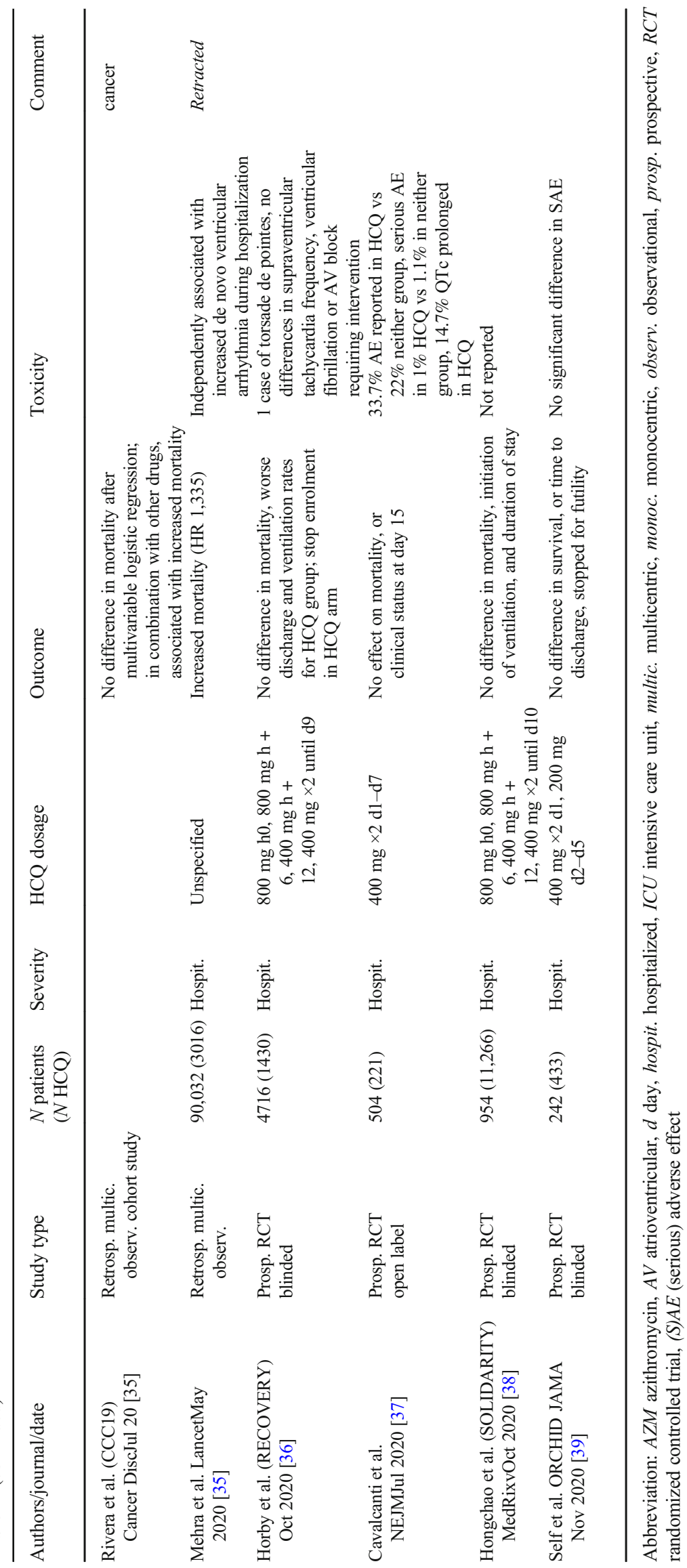


prolongation induced by HCQ. Third, a cumulative effect of additional drug with the potential to prolong QTc may be another explanation (association of HCQ/azithromycin/ lopinavir + ritonavir). This hypothesis is reinforced by the reported increase in cardiac arrest in the HCQ + azithromycin arm of the Rosenberg cohort [32].

\section{HCQ, COVID-19, and autoimmune patients}

In parallel with evaluations of the effect of HCQ in active COVID-19 disease, its use to prevent SARS-CoV-2 infection, as post-exposure prophylaxis or pre-exposure prophylaxis, has been studied. In studies of post-exposure prophylaxis, HCQ has not had a significant preventive effect: in a small, randomized trial of 821 high-risk contacts, asymptomatic patients, an absolute difference of only $2.4 \%$ of clinical infection between controls and HCQ-treated subjects was found [47]. Similar results were found in a cluster, randomized trial in Spain, with 2314 healthy contacts of 672 COVID-19 index cases [48].

Regarding pre-exposure prophylaxis, in a small doubleblind placebo-controlled randomized clinical trial of 132 hospital health workers in the USA (terminated early), there was not a significant difference in incidence of SARS-CoV-2 between HCQ-treated subjects and placebo cohorts [49]. As the World Health Organization stopped recruitment into the HCQ arm in their major randomized controlled trial, the UK regulators authorized HCQ and CQ-related drugs to be given to healthcare workers in a clinical trial, the COPCOV. This trial would see chloroquine, hydroxychloroquine, or a placebo given preventively to more than 40,000 healthcare workers from Europe, Africa, Asia, and South America.

Evaluation of HCQ for prevention of COVID-19 in patients with autoimmune disease patients is an interesting approach, particularly in a supposed at-risk group. Gentry et al. [50] evaluated this potential preventive effect in a retrospective, 3-month study on 10,703 US veterans: compared with 21,406 propensity-matched patients, the HCQ group of patients had no significant decrease in SARS-CoV-2 infection risk $(0.3 \%$ vs $0.4 \%$ rate of infection), with a nonsignificant $\mathrm{OR}$ of 0.79 (CI 0.51-1.20). There were also no differences in hospital admission, ICU requirement, or mortality associated with SARS-CoV-2 infection. But, without explanation, overall mortality during this 3-month period was significantly lower in the HCQ group [50]. Another retrospective observational study, of 6228 patients with autoimmune rheumatic diseases in China [51], found an overall rate of COVID-19 (0.43\%) like that in the US study; the risk of COVID-19 was increased by age and rheumatic disease. After adjustment for age, sex, smoking, contact cases in the family, comorbidities, and SLE (as HCQ is more often prescribed in SLE patients), patients with rheumatic disease taking HCQ had a lower risk of
COVID-19 than did those who were taking other diseasemodifying anti-rheumatic drugs. By contrast, the rate of corticosteroid use in patients with COVID-19 was like that in patients free of COVID-19, around 50\%. Finally, in a retrospective analysis of the Portuguese National Health System, including 26,815 SARS-CoV-2-confirmed patients, after adjustment for age, sex, and chronic treatment with corticosteroids and/or immunosuppressants, the odds ratio of SARSCoV-2 infection for chronic treatment with HCQ was 0.51, also suggesting a protective effect of this drug [52]. Although there is suggestive evidence that autoimmune patients have benefited from the prophylactic use of HCQ during this pandemic, proper randomized clinical studies are needed.

\section{Conclusion}

During the COVID-19 pandemic, HCQ suffers the vagaries of fame. Almost adulated as promising treatment initially, the drug was eventually dismissed as controversial and toxic for patients. The media coverage of this subject has caused confusion amongst the public and within the medical community. In this context, what will be the use of HCQ after the COVID19 pandemic? Will its use in other medical conditions, especially in autoimmune diseases, be affected? What should we expect when SLE patients or patients with other common autoimmune diseases are offered HCQ as a candidate drug? Will it be a negative answer, given the recent misleading publicity about its potential but still unproven toxicity? To correlate the above, we recall a recent encounter where a young male with a history of cutaneous sarcoidosis declined to be treated with HCQ because of the recent emphasis on its cardiac toxicity. As the place of HCQ in the prevention of treatment of COVID-19 is still inconclusive, in this Perspectives in Rheumatology article, we wanted to review the efficacy of HCQ in managing the main autoimmune diseases, HCQ's well-known safety profile, and monitoring recommendation in these conditions. We hope to restore the trusted relationship between patients and their practitioners regarding HCQ use for the management of the commonest autoimmune diseases.

Authorship LP, HY, MMS, and JCY together wrote this manuscript.

\section{Compliance with ethical standards}

Disclosures None.

\section{References}

1. Pothen L, Yildiz H, De Greef J, Penaloza A, Beauloye C, Belkhir L, Yombi JC (2020) Safe use of hydroxychloroquine and its combination with azithromycin in the context of Sars-CoV-2 outbreak: 
clinical experience in a Belgian tertiary center. Travel Med Infect Dis 36:101788. https://doi.org/10.1016/j.tmaid.2020.101788

2. Schrezenmeier E, Dorner T (2020) Mechanisms of action of hydroxychloroquine and chloroquine: implications for rheumatology. Nat Rev Rheumatol 16(3):155-166. https://oi.org/10.1038/ s41584-020-0372-x

3. Dos Reis Neto ET, Kakehasi AM, de Medeiros Pinheiro M, Ferreira GA, Marques CDL, da Mota LMH, Dos Santos Paiva E, Pileggi GCS, Sato EI, Reis A, Xavier RM, Provenza JR (2020) Revisiting hydroxychloroquine and chloroquine for patients with chronic immunity-mediated inflammatory rheumatic diseases. Adv Rheumatol 60(1):32. https://doi.org/10.1186/s42358-020-00134-8

4. Fanouriakis A, Kostopoulou M, Alunno A, Aringer M, Bajema I, Boletis JN, Cervera R, Doria A, Gordon C, Govoni M, Houssiau F, Jayne D, Kouloumas M, Kuhn A, Larsen JL, Lerstrom K, Moroni G, Mosca M, Schneider M, Smolen JS, Svenungsson E, Tesar V, Tincani A, Troldborg A, van Vollenhoven R, Wenzel J, Bertsias G, Boumpas DT (2019) 2019 update of the EULAR recommendations for the management of systemic lupus erythematosus. Ann Rheum Dis 78(6):736-745. https://doi.org/10.1136/annrheumdis-2019215089

5. A randomized trial of hydroxychloroquine in early rheumatoid arthritis: the HERA Study (1995) Am J Med 98(2):156-168. https:// doi.org/10.1016/s0002-9343(99)80399-4

6. Sharma TS, Wasko MC, Tang X, Vedamurthy D, Yan X, Cote J, Bili A (2016) Hydroxychloroquine use is associated with decreased incident cardiovascular events in rheumatoid arthritis patients. J Am Heart Assoc 5(1). https://doi.org/10.1161/JAHA.115.002867

7. Ruiz-Irastorza G, Olivares N, Ruiz-Arruza I, Martinez-Berriotxoa A, Egurbide MV, Aguirre C (2009) Predictors of major infections in systemic lupus erythematosus. Arthritis Res Ther 11(4):R109. https://doi.org/10.1186/ar2764

8. Bultink IE, Hamann D, Seelen MA, Hart MH, Dijkmans BA, Daha MR, Voskuyl AE (2006) Deficiency of functional mannosebinding lectin is not associated with infections in patients with systemic lupus erythematosus. Arthritis Res Ther 8(6):R183. https://doi.org/10.1186/ar2095

9. Smitten AL, Choi HK, Hochberg MC, Suissa S, Simon TA, Testa MA, Chan KA (2008) The risk of hospitalized infection in patients with rheumatoid arthritis. J Rheumatol 35(3):387-393

10. Rolain JM, Colson P, Raoult D (2007) Recycling of chloroquine and its hydroxyl analogue to face bacterial, fungal and viral infections in the 21st century. Int J Antimicrob Agents 30(4):297-308. https://doi.org/10.1016/j.jiantimicag.2007.05.015

11. Jorge A, Ung C, Young LH, Melles RB, Choi HK (2018) Hydroxychloroquine retinopathy - implications of research advances for rheumatology care. Nat Rev Rheumatol 14(12):693703. https://doi.org/10.1038/s41584-018-0111-8

12. Fiehn C, Ness T, Weseloh C, Specker C, Hadjiski D, Detert J, Kruger K, Pharmakotherapie DGK (2020) Safety management in treatment with antimalarials in rheumatology. Interdisciplinary recommendations on the basis of a systematic literature review. Z Rheumatol. https://doi.org/10.1007/s00393-020-00785-4

13. Traebert M, Dumotier B, Meister L, Hoffmann P, DominguezEstevez M, Suter W (2004) Inhibition of hERG K+ currents by antimalarial drugs in stably transfected HEK293 cells. Eur J Pharmacol 484(1):41-48. https://doi.org/10.1016/j.ejphar.2003.11. 003

14. Chen CY, Wang FL, Lin CC (2006) Chronic hydroxychloroquine use associated with QT prolongation and refractory ventricular arrhythmia. Clin Toxicol (Phila) 44(2):173-175. https://doi.org/10. 1080/15563650500514558

15. McGhie TK, Harvey P, Su J, Anderson N, Tomlinson G, Touma Z (2018) Electrocardiogram abnormalities related to anti-malarials in systemic lupus erythematosus. Clin Exp Rheumatol 36(4):545-551
16. Risch HA (2020) Early outpatient treatment of symptomatic, highrisk COVID-19 patients that should be ramped up immediately as key to the pandemic crisis. Am J Epidemiol 189(11):1218-1226. https://doi.org/10.1093/aje/kwaa093

17. Yao X, Ye F, Zhang M, Cui C, Huang B, Niu P, Liu X, Zhao L, Dong E, Song C, Zhan S, Lu R, Li H, Tan W, Liu D (2020) In vitro antiviral activity and projection of optimized dosing design of hydroxychloroquine for the treatment of severe acute respiratory syndrome coronavirus 2 (SARS-CoV-2). Clin Infect Dis 71(15): 732-739. https://doi.org/10.1093/cid/ciaa237

18. Funnell SGP, Dowling WE, Munoz-Fontela C, Gsell PS, Ingber DE, Hamilton GA, Delang L, Rocha-Pereira J, Kaptein S, Dallmeier KH, Neyts J, Rosenke K, de Wit E, Feldmann H, Maisonnasse P, Le Grand R, Frieman MB, Coleman CM (2020) Emerging preclinical evidence does not support broad use of hydroxychloroquine in COVID-19 patients. Nat Commun 11(1): 4253. https://doi.org/10.1038/s41467-020-17907-w

19. Zhang J, Tecson KM, McCullough PA (2020) Endothelial dysfunction contributes to COVID-19-associated vascular inflammation and coagulopathy. Rev Cardiovasc Med 21(3):315-319. https:// doi.org/10.31083/j.rcm.2020.03.126

20. Zhaowei Chen JH, Zhang Z, Jiang S, Han S, Yan D, Zhuang R, Ben H, Zhang Z (2020) Efficacy of hydroxychloroquine in patients with COVID-19: results of a randomized clinical trial. MedRixv. https:// doi.org/10.1101/2020.03.22.20040758

21. Nikolas Bernaola RM, Bernaola A, Lara A, Carballo C, Larranaga P, Bielza C (2020) Observational study of the efficiency of treatments in patients hospitalized with covid-19 in Madrid. MedRixv. https://doi.org/10.1101/2020.07.17.20155960

22. Million M, Lagier JC, Gautret P, Colson P, Fournier PE, Amrane S, Hocquart M, Mailhe M, Esteves-Vieira V, Doudier B, Aubry C, Correard F, Giraud-Gatineau A, Roussel Y, Berenger C, Cassir N, Seng P, Zandotti C, Dhiver C, Ravaux I, Tomei C, Eldin C, TissotDupont H, Honore S, Stein A, Jacquier A, Deharo JC, Chabriere E, Levasseur A, Fenollar F, Rolain JM, Obadia Y, Brouqui P, Drancourt M, La Scola B, Parola P, Raoult D (2020) Early treatment of COVID-19 patients with hydroxychloroquine and azithromycin: a retrospective analysis of 1061 cases in Marseille, France. Travel Med Infect Dis 35:101738. https://doi.org/10.1016/j. tmaid.2020.101738

23. Emilie Sbidian JJ, Lemaitre G, Mayer I, Bernaux M, Gramfort A, Lapidus N, Paris N, Neuraz A, Lerner I, Garcelon N, Rance B, Grisel O, Moreau T, Bellamine A, Wolkenstein P, Varoquaux G, Caumes E, Lavielle M, Dessap AM, Audureau E (2020) Hydroxychloroquine with or without azithromycin and in-hospital mortality or discharge in patients hospitalized for COVID-19 infection: a cohort study of 4,642 in-patients in France. MedRixv. https:// doi.org/10.1101/2020.06.16.20132597

24. Yu B, Li C, Chen P, Li J, Jiang H, Wang DW (2020) Beneficial effects exerted by hydroxychloroquine in treating COVID-19 patients via protecting multiple organs. Sci China Life Sci. https://doi. org/10.1007/s11427-020-1782-1

25. Catteau L, Dauby N, Montourcy M, Bottieau E, Hautekiet J, Goetghebeur E, van Ierssel S, Duysburgh E, Van Oyen H, Wyndham-Thomas C, Van Beckhoven D, Belgian Collaborative Group on C-HS (2020) Low-dose hydroxychloroquine therapy and mortality in hospitalised patients with COVID-19: a nationwide observational study of 8075 participants. Int J Antimicrob Agents 56(4):106144. https://doi.org/10.1016/j.ijantimicag.2020.106144

26. Di Castelnuovo A, Bonaccio M, Costanzo S, Gialluisi A, Antinori A, Berselli N, Blandi L, Bruno R, Cauda R, Guaraldi G, My I, Menicanti L, Parruti G, Patti G, Perlini S, Santilli F, Signorelli C, Stefanini GG, Vergori A, Abdeddaim A, Ageno W, Agodi A, Agostoni P, Aiello L, Al Moghazi S, Aucella F, Barbieri G, Bartoloni A, Bologna C, Bonfanti P, Brancati S, Cacciatore F, Caiano L, Cannata F, Carrozzi L, Cascio A, Cingolani A, 
Cipollone F, Colomba C, Crisetti A, Crosta F, Danzi GB, D’Ardes D, de Gaetano Donati K, Di Gennaro F, Di Palma G, Di Tano G, Fantoni M, Filippini T, Fioretto P, Fusco FM, Gentile I, Grisafi L, Guarnieri G, Landi F, Larizza G, Leone A, Maccagni G, Maccarella S, Mapelli M, Maragna R, Marcucci R, Maresca G, Marotta C, Marra L, Mastroianni F, Mengozzi A, Menichetti F, Milic J, Murri R, Montineri A, Mussinelli R, Mussini C, Musso M, Odone A, Olivieri M, Pasi E, Petri F, Pinchera B, Pivato CA, Pizzi R, Poletti V, Raffaelli F, Ravaglia C, Righetti G, Rognoni A, Rossato M, Rossi M, Sabena A, Salinaro F, Sangiovanni V, Sanrocco C, Scarafino A, Scorzolini L, Sgariglia R, Simeone PG, Spinoni E, Torti C, Trecarichi EM, Vezzani F, Veronesi G, Vettor R, Vianello A, Vinceti M, De Caterina R, Iacoviello L, RISk CO-, Treatments c (2020) Common cardiovascular risk factors and inhospital mortality in 3,894 patients with COVID-19: survival analysis and machine learning-based findings from the multicentre Italian CORIST Study. Nutr Metab Cardiovasc Dis 30(11):18991913. https://doi.org/10.1016/j.numecd.2020.07.031

27. Arshad S, Kilgore P, Chaudhry ZS, Jacobsen G, Wang DD, Huitsing K, Brar I, Alangaden GJ, Ramesh MS, McKinnon JE, O'Neill W, Zervos M, Henry Ford C-TF (2020) Treatment with hydroxychloroquine, azithromycin, and combination in patients hospitalized with COVID-19. Int J Infect Dis 97:396-403. https:// doi.org/10.1016/j.ijid.2020.06.099

28. Lagier JC, Million M, Gautret P, Colson P, Cortaredona S, GiraudGatineau A, Honore S, Gaubert JY, Fournier PE, Tissot-Dupont H, Chabriere E, Stein A, Deharo JC, Fenollar F, Rolain JM, Obadia Y, Jacquier A, La Scola B, Brouqui P, Drancourt M, Parola P, Raoult D, force IC-T (2020) Outcomes of 3,737 COVID-19 patients treated with hydroxychloroquine/azithromycin and other regimens in Marseille, France: a retrospective analysis. Travel Med Infect Dis 36:101791. https://doi.org/10.1016/j.tmaid.2020.101791

29. Ayerbe L, Risco-Risco C, Ayis S (2020) The association of treatment with hydroxychloroquine and hospital mortality in COVID19 patients. Intern Emerg Med 15(8):1501-1506. https://doi.org/10. 1007/s11739-020-02505-x

30. Lammers AJJ, Brohet RM, Theunissen REP, Koster C, Rood R, Verhagen DWM, Brinkman K, Hassing RJ, Dofferhoff A, El Moussaoui R, Hermanides G, Ellerbroek J, Bokhizzou N, Visser H, van den Berge M, Bax H, Postma DF, Groeneveld PHP (2020) Early hydroxychloroquine but not chloroquine use reduces ICU admission in COVID-19 patients. Int J Infect Dis. https://doi.org/ 10.1016/j.ijid.2020.09.1460

31. Ip A, Berry DA, Hansen E, Goy AH, Pecora AL, Sinclaire BA, Bednarz U, Marafelias M, Berry SM, Berry NS, Mathura S, Sawczuk IS, Biran N, Go RC, Sperber S, Piwoz JA, Balani B, Cicogna C, Sebti R, Zuckerman J, Rose KM, Tank L, Jacobs LG, Korcak J, Timmapuri SL, Underwood JP, Sugalski G, Barsky C, Varga DW, Asif A, Landolfi JC, Goldberg SL (2020) Hydroxychloroquine and tocilizumab therapy in COVID-19 patients-an observational study. PLoS One 15(8):e0237693. https:// doi.org/10.1371/journal.pone.0237693

32. Rosenberg ES, Dufort EM, Udo T, Wilberschied LA, Kumar J, Tesoriero J, Weinberg P, Kirkwood J, Muse A, DeHovitz J, Blog DS, Hutton B, Holtgrave DR, Zucker HA (2020) Association of treatment with hydroxychloroquine or azithromycin with inhospital mortality in patients with COVID-19 in New York State. JAMA 323(24):2493-2502. https://doi.org/10.1001/jama.2020. 8630

33. Shailendra Singh AK, Chowdhry M, Chatterjee A (2020) Outcomes of hydroxychloroquine treatment among hospitalized COVID-19 patients in the United States- real-world evidence from a federated electronic medical record network. MedRixv. https:// doi.org/10.1101/2020.05.12.20099028

34. Geleris J, Sun Y, Platt J, Zucker J, Baldwin M, Hripcsak G, Labella A, Manson DK, Kubin C, Barr RG, Sobieszczyk ME, Schluger
NW (2020) Observational study of hydroxychloroquine in hospitalized patients with Covid-19. N Engl J Med 382(25):2411-2418. https://doi.org/10.1056/NEJMoa2012410

35. Mehra MR, Desai SS, Ruschitzka F, Patel AN (2020) RETRACTED: Hydroxychloroquine or chloroquine with or without a macrolide for treatment of COVID-19: a multinational registry analysis. Lancet. https://doi.org/10.1016/S0140-6736(20) 31180-6

36. Peter Horby MM, Linsell L, Bell JL, Staplin N, Emberson JR, Wiselka M, Ustianowski A, Elmahi E, Prudon B, Whitehouse A, Felton T, Williams J, Faccenda J, Underwood J, Baillie K, Chappell L, Faust SN, Jaki T, Jeffery K, Lim WS, Montgomery A, Rowan K, Tarning J, Watson JA, White NJ, Juszczak E, Haynes R, Martin J Landray RECOVERY (2020) Effect of hydroxychloroquine in hospitalized patients with COVID-19: preliminary results from a multicentre, randomized, controlled trial. MedRxiv. https://doi.org/10. 1101/2020.07.15.20151852

37. Cavalcanti AB, Zampieri FG, Rosa RG, Azevedo LCP, Veiga VC, Avezum A, Damiani LP, Marcadenti A, Kawano-Dourado L, Lisboa T, Junqueira DLM, de Barros ESPGM, Tramujas L, Abreu-Silva EO, Laranjeira LN, Soares AT, Echenique LS, Pereira AJ, Freitas FGR, Gebara OCE, Dantas VCS, Furtado RHM, Milan EP, Golin NA, Cardoso FF, Maia IS, Hoffmann Filho CR, Kormann APM, Amazonas RB, Bocchi de Oliveira MF, Serpa-Neto A, Falavigna M, Lopes RD, Machado FR, Berwanger O, Coalition Covid-19 Brazil II (2020) Hydroxychloroquine with or without azithromycin in mild-tomoderate Covid-19. N Engl J Med. https://doi.org/10.1056/ NEJMoa2019014

38. WHO Solidarity trial Consortium HP, Peto R et al (2020) Repurposed antiviral drugs for COVID-19 -interim WHO SOLIDARITY trial results. MedRixv. https://doi.org/10.1101/ 2020.10.15.20209817

39. Self WH, Semler MW, Leither LM, Casey JD, Angus DC, Brower RG, Chang SY, Collins SP, Eppensteiner JC, Filbin MR, Files DC, Gibbs KW, Ginde AA, Gong MN, Harrell FE Jr, Hayden DL, Hough CL, Johnson NJ, Khan A, Lindsell CJ, Matthay MA, Moss M, Park PK, Rice TW, Robinson BRH, Schoenfeld DA, Shapiro NI, Steingrub JS, Ulysse CA, Weissman A, Yealy DM, Thompson BT, Brown SM, National Heart L, Blood Institute PCTN (2020) Effect of hydroxychloroquine on clinical status at 14 days in hospitalized patients with COVID-19: a randomized clinical trial. JAMA. https://doi.org/10.1001/jama.2020.22240

40. Rivera DR, Peters S, Panagiotou OA, Shah DP, Kuderer NM, Hsu CY, Rubinstein SM, Lee BJ, Choueiri TK, de Lima Lopes G Jr, Grivas P, Painter CA, Rini BI, Thompson MA, Arcobello J, Bakouny Z, Doroshow DB, Egan PC, Farmakiotis D, Fecher LA, Friese CR, Galsky MD, Goel S, Gupta S, Halfdanarson TR, Halmos B, Hawley JE, Khaki AR, Lemmon CA, Mishra S, Olszewski AJ, Pennell NA, Puc MM, Revankar SG, Schapira L, Schmidt A, Schwartz GK, Shah SA, Wu JT, Xie Z, Yeh AC, Zhu H, Shyr Y, Lyman GH, Warner JL, Covid CC (2020) Utilization of COVID-19 treatments and clinical outcomes among patients with cancer: a COVID-19 and Cancer Consortium (CCC19) Cohort Study. Cancer Discov 10(10):1514-1527. https://doi.org/10.1158/21598290.CD-20-0941

41. Dauby N, Bottieau E (2020) The unfinished story of hydroxychloroquine in COVID-19: the right anti-inflammatory dose at the right moment? Int J Infect Dis. https://doi.org/10. 1016/j.ijid.2020.10.032

42. Mercuro NJ, Yen CF, Shim DJ, Maher TR, McCoy CM, Zimetbaum PJ, Gold HS (2020) Risk of QT interval prolongation associated with use of hydroxychloroquine with or without concomitant azithromycin among hospitalized patients testing positive for coronavirus disease 2019 (COVID-19). JAMA Cardiol 5(9): 1036-1041. https://doi.org/10.1001/jamacardio.2020.1834 
43. Gerard A, Romani S, Fresse A, Viard D, Parassol N, Granvuillemin A, Chouchana L, Rocher F, Drici MD, French Network of Pharmacovigilance C (2020) "Off-label" use of hydroxychloroquine, azithromycin, lopinavir-ritonavir and chloroquine in COVID-19: a survey of cardiac adverse drug reactions by the French Network of Pharmacovigilance Centers. Therapie 75(4): 371-379. https://doi.org/10.1016/j.therap.2020.05.002

44. Gasperetti A, Biffi M, Duru F, Schiavone M, Ziacchi M, Mitacchione G, Lavalle C, Saguner A, Lanfranchi A, Casalini G, Tocci M, Fabbricatore D, Salghetti F, Mariani MV, Busana M, Bellia A, Cogliati CB, Viale P, Antinori S, Galli M, Galie N, Tondo C, Forleo GB (2020) Arrhythmic safety of hydroxychloroquine in COVID-19 patients from different clinical settings. Europace. https://doi.org/10.1093/europace/euaa216

45. Bhatla A, Mayer MM, Adusumalli S, Hyman MC, Oh E, Tierney A, Moss J, Chahal AA, Anesi G, Denduluri S, Domenico CM, Arkles J, Abella BS, Bullinga JR, Callans DJ, Dixit S, Epstein AE, Frankel DS, Garcia FC, Kumareswaram R, Nazarian S, Riley MP, Santangeli P, Schaller RD, Supple GE, Lin D, Marchlinski F, Deo R (2020) COVID-19 and cardiac arrhythmias. Heart Rhythm 17(9):1439-1444. https://doi.org/10.1016/j.hrthm.2020.06.016

46. Kunutsor SK, Laukkanen JA (2020) Renal complications in COVID-19: a systematic review and meta-analysis. Ann Med 52(7):345-353. https://doi.org/10.1080/07853890.2020.1790643

47. Boulware DR, Pullen MF, Bangdiwala AS, Pastick KA, Lofgren SM, Okafor EC, Skipper CP, Nascene AA, Nicol MR, Abassi M, Engen NW, Cheng MP, LaBar D, Lother SA, MacKenzie LJ, Drobot G, Marten N, Zarychanski R, Kelly LE, Schwartz IS, McDonald EG, Rajasingham R, Lee TC, Hullsiek KH (2020) A randomized trial of hydroxychloroquine as postexposure prophylaxis for Covid-19. N Engl J Med 383(6):517-525. https://doi.org/ 10.1056/NEJMoa2016638

48. Mitja O, Corbacho-Monne M, Ubals M, Alemany A, Suner C, Tebe C, Tobias A, Penafiel J, Ballana E, Perez CA, Admella P, RieraMarti N, Laporte P, Mitja J, Clua M, Bertran L, Sarquella M, Gavilan S, Ara J, Argimon JM, Cuatrecasas G, Canadas P,
Elizalde-Torrent A, Fabregat R, Farre M, Forcada A, FloresMateo G, Lopez C, Muntada E, Nadal N, Narejos S, Nieto A, Prat N, Puig J, Quinones C, Ramirez-Viaplana F, Reyes-Uruena J, Riveira-Munoz E, Ruiz L, Sanz S, Sentis A, Sierra A, Velasco C, Vivanco-Hidalgo RM, Zamora J, Casabona J, Vall-Mayans M, Gonzalez-Beiras C, Clotet B, Group BC-P-CR (2020) A clusterrandomized trial of hydroxychloroquine for prevention of Covid19. N Engl J Med. https://doi.org/10.1056/NEJMoa2021801

49. Abella BS, Jolkovsky EL, Biney BT, Uspal JE, Hyman MC, Frank I, Hensley SE, Gill S, Vogl DT, Maillard I, Babushok DV, Huang AC, Nasta SD, Walsh JC, Wiletyo EP, Gimotty PA, Milone MC, Amaravadi RK, the P, Treatment of C-WHI (2020) Efficacy and safety of hydroxychloroquine vs placebo for pre-exposure SARSCoV-2 prophylaxis among health care workers: a randomized clinical trial. JAMA Intern Med. https://doi.org/10.1001/ jamainternmed.2020.6319

50. Gentry CA, Humphrey MB, Thind SK, Hendrickson SC, Kurdgelashvili G, Williams RJ, 2nd (2020) Long-term hydroxychloroquine use in patients with rheumatic conditions and development of SARS-CoV-2 infection: a retrospective cohort study. Lancet Rheumatol 2 (11):e689-e697. doi:https://doi.org/10. 1016/S2665-9913(20)30305-2

51. Zhong J, Shen G, Yang H, Huang A, Chen X, Dong L, Wu B, Zhang A, Su L, Hou X, Song S, Li H, Zhou W, Zhou T, Huang Q, Chu A, Braunstein Z, Rao X, Ye C, Dong L (2020) COVID-19 in patients with rheumatic disease in Hubei province, China: a multicentre retrospective observational study. Lancet Rheumatol 2(9):e557-e564. https://doi.org/10.1016/S2665-9913(20)30227-7

52. Ferreira A, Oliveira ESA, Bettencourt P (2020) Chronic treatment with hydroxychloroquine and SARS-CoV-2 infection. J Med Virol. https://doi.org/10.1002/jmv.26286

Publisher's note Springer Nature remains neutral with regard to jurisdictional claims in published maps and institutional affiliations. 